\title{
In vitro assessment of the cytotoxic effects of novel RGD analogues
}

\author{
Anelia Balacheva ${ }^{1}$, Ivan Iliev ${ }^{2}$, Roumyana Detcheva ${ }^{1}$, Tatyana Dzimbova ${ }^{1}$, Tamara \\ Pajpanova $^{1 *}$, Evgeny Golovinsky ${ }^{1}$
}

\begin{abstract}
${ }^{1}$ Institute of Molecular Biology "Roumen Tsanev”, Bulgarian Academy of Sciences, Acad. G. Bonchev Str., block 21, Sofia 1113, Bulgaria ${ }^{2}$ Institute of Experimental Morphology, Pathology and Anthropology with Museum, Bulgarian Academy of Sciences, Acad. G. Bonchev Str., block 25, Sofia 1113, Bulgaria
\end{abstract}

\begin{abstract}
The RGD sequence is present in many extracellular matrix proteins and intracellular proteins, including caspases. Synthetic RGD peptides may affect adhesion, migration and tumour metastasis, or directly induce apoptosis. Several RGD peptides were synthesized, and their anti-adhesive and cytotoxic properties were analyzed in vitro. Here we present the cytotoxic activities of RGD, R(NO $\mathrm{NO}_{2}$ GD, CavGD and RGD-OMe on non-tumour $3 \mathrm{~T} 3$ cells and tumour cell lines HepG2 and MCF-7. The cell growth inhibitory effects of RGD-OMe are significantly higher than those of RGD on the cell lines used. Evidently the modification in the carboxylic group of RGD with simple esterification increases the cell growth inhibitory effects of the parent compound.
\end{abstract}

Citation: Balacheva A, Iliev I, Detcheva R, Dzimbova T, Pajpanova T, Golovinsky E. In vitro assessment of the cytotoxic effects of novel RGD analogues. BioDiscovery 2012; 4: 1; DOI: 10.7750/BioDiscovery.2012.4.1

Copyright: ( 2012 Balatcheva et al. This is an open-access article distributed under the terms of the Creative Commons Attribution License, which permits unrestricted use, provided the original authors and source are credited.

Received: 31 July 2012; Revised: 13 October2012; Accepted: 16 October 2012; Available online/Published: 23 October 2012

Keywords: RGD, cytotoxic activity, canavanine

"Corresponding Author: Tamara Pajpanova, e-mail: tamara@bio21.bas.bg

Conflict of Interests: No potential conflict of interest was disclosed and there is not any competing financial interest in relation to the work described.

\section{Introduction}

Among the peptide family, short peptides are very appealing for drug discovery and development because of their cost-effectiveness, possibility of oral administration, and simplicity to perform molecular structural and quantitative structure-activity studies [1]. Small peptides are under development as possible antitumour agents as well. Examples of these are peptides with RGD (L-argininylglycyl-L-aspartic acid) or NGR (L-aspartylglycine-L-arginine) motifs presented in fibronectin, laminin, vitronectin, fibrinogen and collagens $[2,3]$. The discovery of the minimal peptide sequence RGD, which plays a prominent role in cell adhesion via integrin interaction, has led to a large increase in biomedical and biomaterials research on this motif. RGD peptides are commonly known as antimetastatic agents and are able to decrease the number of spontaneous and experimental metastases in in vivo models [4-7]. Moreover, descriptions exist of some of their in vitro activities, like inhibition of tumour cell adhesion to extracellular matrix proteins and the inhibition of migration in a three dimensional gel $[6$, $8,9]$.

Various RGD-containing peptides have been increasingly developed for adapting to versatile applications including tumor imaging and therapy, drug delivery vector, targeted gene transfer, and biomaterial or tissue engineering. Significant progress has been 
made in the discovery and development of integrin $\alpha_{v} \alpha_{3}-$ specific linear and cyclic RGD peptide analogs such as cilengitide and c(RGDfK) for cancer therapy, as well as targeted delivery of cancer imaging and therapeutic agents. Examples of such radio-imaging agents include [99mTc]apticide, which can be used in imaging deep vein thrombosis [10]. Several modifications of RGD peptides, including polymerisation, coupling with carriers and substitution by peptidomimetics, were performed to enhance the anti-tumour properties and lengthen the degradation time in vivo [11-14]. RGD peptides conjugated with different cytostatic agents are likely to exhibit an antitumour and antiangiogenic synergetic effect. During the last few years, a number of RGD-cytotoxic drugs were developed and showed promising activities in vitro and in vivo $[15,16]$.

Despite the few RGD analogues being approved for clinical use, development of orally active RGD peptidomimetics have been significantly hindered because of low bioavailabilities. This is largely due to the metabolic lability of this class of compounds in the presence of proteases and peptidases and because of their high polarity and charge. Wang et al. [17] published a detailed review of peptidomimetic analogues of RGD and the strategies used to enhance their bioavailability.

In this context, drug design based on the RGD structure may provide opportunity for targeted drug deliveries, high resolution imaging of cancerous tissues and organs, as well as new chemotherapeutic treatments for cancer.

Following our long-term program for the design of biologically active peptides based on the non-protein amino acids, we synthesized several short RGD-mimetics containing the sequence Xaa-GD, where Xaa is Arg or Arg-mimetic (Figure 1) with a view to improve its cytotoxic activity [18].
The purpose of this study, therefore was to investigate the cytotoxic activities of RGD and its newly synthesized mimetics (2-4) on non-tumour 3T3 cells and tumour cell lines HepG2 and MCF-7.

\section{Results}

The RGD analogues were synthesized following a procedure previously reported [18]. For the synthesis of peptides 1-3 standard Fmoc-SPPS was applied using HBTU as a coupling reagent. Peptide deprotection and cleavage from the resin were carried out in a mixture of TFA and scavengers. The peptide 4 was prepared by classical solution procedure. We were able to obtain the RGD mimetics with satisfactory purities (typically $>95 \%$ ), as assessed by analytical HPLC (Figure 2). Furthermore the stability of the peptides (2-4) has been proven during $24 \mathrm{~h}$ period. The peptide analogues were quite stable in aqueous solution. For example, the decomposition of RGD-OMe after $24 \mathrm{~h}$ incubation in culture medium at $37^{\circ} \mathrm{C}$ was less than $2 \%$, as assessed by UV-spectroscopy and analytical HPLC.

The results of the cytotoxicity of RGD and RGD$\mathrm{OMe}$ on non-tumour 3T3 cells and tumour cell lines HepG2 and MCF-7 are shown in Figure 3. The cells were exposed for 24 hours to different concentrations (ranging from 2 to $0.015 \mathrm{mM}$ ) of the compounds. As seen in Figure 3. treatment of the cell lines resulted in a dosedependent reduction of the number of the viable cells. The RGD analogue RGD-OMe exhibited higher cell growth inhibitory effects on the three cell lines compared to its parent compound. Statistically reliable results for the cytotoxic action of RGD-OMe on HepG2 and MCF-7 cells were achieved for the most of concentrations used.

The cytotoxic activity of the synthesized peptides<smiles>[R14]C=CC[C@H](N)C(=O)NCC(=O)N[C@@H](CC(=O)O)C(=O)O</smiles><smiles>[R]NC(=N)N[X]CCC(N)C([R7])=O</smiles>

Xaa:

1. $\operatorname{Arg}\left(\mathrm{X}=\mathrm{CH}_{2}, \mathrm{R}=\mathrm{H}, \mathrm{R}_{1}=\mathrm{OH}\right)$;

2. $\operatorname{Arg}\left(\mathrm{X}=\mathrm{CH}_{2}, \mathrm{R}=\mathrm{NO}_{2}, \mathrm{R}_{1}=\mathrm{OH}\right)$;

3. $\mathrm{C}$ av $\left(\mathrm{X}=\mathrm{O}, \mathrm{R}=\mathrm{H}, \mathrm{R}_{1}=\mathrm{OH}\right)$;

4. $\operatorname{Arg}\left(X=\mathrm{CH}_{2}, \mathrm{R}=\mathrm{H}, \mathrm{R}{ }_{1}=\mathrm{OMe}\right)$.

Figure 1. Structure of RGD and analogues: Arg-Gly-Asp (RGD, 1); $\left.\operatorname{Arg}(\mathrm{NO} 2)-G l y-A s p\left(\mathrm{R}_{(\mathrm{NO}}\right) \mathrm{GD}, 2\right)$; Cav-Gly-Asp (CavGD, 3); Arg-Gly-Asp-methyl ester (RGD-OMe 4). 

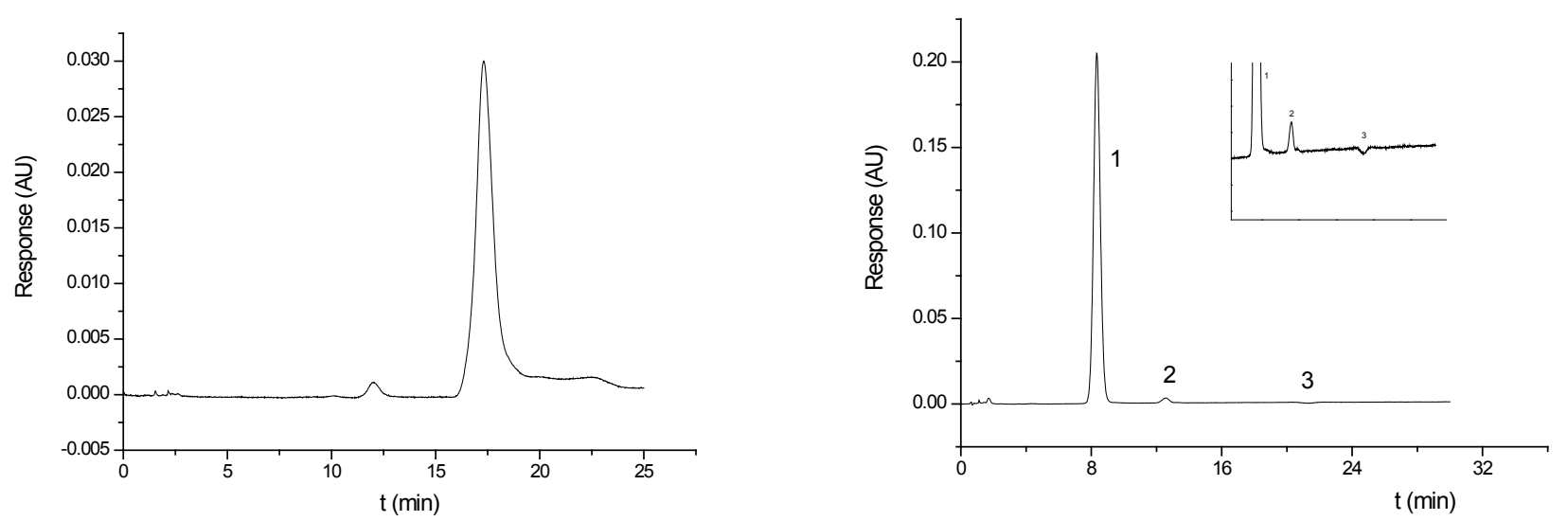

Figure 2. HPLC-chromatograms of peptides 3 and 4. Chromatographic conditions: column: Atlantis ${ }^{\mathrm{TM}} \mathrm{dC}_{18}, 4.6 \times 150 \mathrm{~mm}$, particle size $5 \mu \mathrm{m}$, mobile phase: acetonitrile/deionised water $40 / 60(\mathrm{v} / \mathrm{v})$, column and sample temperature: $25^{\circ} \mathrm{C}$, flow rate: $1 \mathrm{ml} / \mathrm{min}, \mathrm{UV}$ detection - $206 \mathrm{~nm}$.
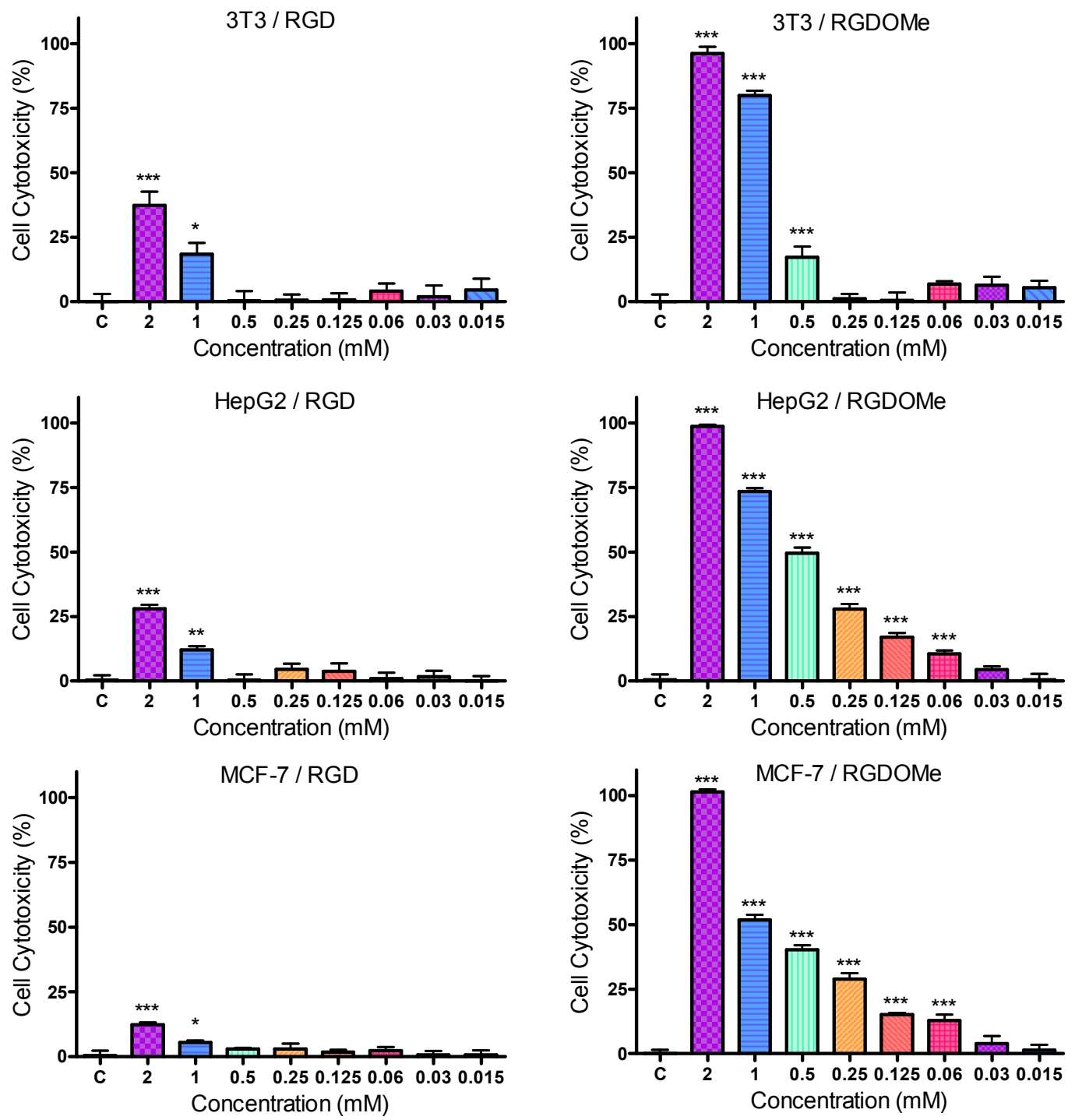

Figure 3. Effect of RGD and RGD-OMe on growth of 3T3, HepG2 and MCF-7 cells after $24 \mathrm{~h}$ of treatment. Cell cytotoxicity determined by MTT assay is expressed as per cent of dead cells and presented as mean \pm SD $(n=6)$, $* * * \mathrm{P}<0.001,{ }^{*} * \mathrm{P}<0.01, * \mathrm{P}<0.05$, ANOVA-test, versus the control group. $\mathrm{C}-$ control. 
(1-4) is demonstrated by calculating the half maximal inhibitory concentrations $\left(\mathrm{IC}_{50}\right.$ values $)$, shown in Table 1 . IC50 values of 1-3, in 3T3, HepG2 and MCF-7 are $>2 \mathrm{mM}$ (Table 1). IC50 values of RGD-OMe in 3T3, HepG2 and MCF-7 are $0.758,0.524$ and 0.927 respectively. Evidently HepG2 is the most sensitive of the three cell lines to the cytotoxic effects of the RGD-OMe.

Table 1. Comparative cytotoxic activity of RGD and its analogues $\mathrm{R}\left(\mathrm{NO}_{2}\right) \mathrm{GD}$, CavGD and RGD-OMe in 3T3, HepG2 and MCF-7 cells after $24 \mathrm{~h}$ treatment (MTT-dye reduction assay).

\begin{tabular}{cccc}
\hline Peptides & \multicolumn{3}{c}{ Mean IC 50 $^{\text {values }(\mathrm{mM}) *}$} \\
& $\mathbf{3 T 3}$ & HepG2 & MCF-7 \\
RGD & $>2$ & $>2$ & $>2$ \\
R(NO $)$ GD & $>2$ & $>2$ & $>2$ \\
CavGD & $>2$ & $>2$ & $>2$ \\
RGD-OMe & $0.758 \pm 0.0504$ & $0.524 \pm 0.0766$ & $0.927 \pm 0.1066$ \\
\hline
\end{tabular}

HepG2 cells, treated with RGD and RGD-OMe were investigated for damages in their genomic DNA by neutral variant of Comet assay. The obtained by us Comet assay data confirmed that the RGD and RGD-OMe revealed certain DNA damaging activity, i.e. genotoxicity, which was increasing with the modifications of the compound (results not published). In an attempt to look deeper in the details of the observed genotoxicity we searched for consequence of the compounds on the cell cycle. The FACS analysis, however, has not proposed evidence of distinctive influence of the studied compounds on the stages of cell cycle. This result show that even strongly pronounced the genotoxic activity of the compounds is not connected with certain check point of the cell cycle (results not published).

\section{Discussion}

Peptides containing unusual amino acids are used in a multitude of applications including structural activity studies, diagnostics, and new drug discovery, improvements in bioavailability, molecular markers, and biologically active pharmaceuticals.

We decided to carry out various structural modifications on $\mathrm{N}$ - and C-terminal of the RGD molecule [18]. We chose for example, unnatural amino acid L-canavanine (Cav), as a promising candidate for the synthesis of RGD analogues, instead of the basic residue Arg.

As shown by several authors, Cav a structural analogue of Arg, possesses growth retardation activity toward tumor cells in culture and experimental tumors in vivo [19-21]. We supposed that modification with the structural analogue and antimetabolite of Arg, will improve the antitumor activity of the parent molecule.
The cytotoxic activities of peptides $\mathbf{2}$ and $\mathbf{3}$ on 3T3 and HepG2 cells were examined (results not shown) but only the highest concentration used $(2 \mathrm{mM})$ revealed cell growth inhibitory effect. Next, we decided to perform an experiment with C-terminal modified RGD. For this purpose we synthesized RGD-OMe 4.

The results showed that the cell growth inhibitory effects of $\mathbf{4}$ are significantly higher than those of RGD on the three cell lines. Evidently, the modification in the carboxylic group of RGD with simple esterification increases the cell growth inhibitory effects of the parent compound.

The effect of RGD-OMe is higher in the case of the tumor cells HepG2 in comparison with non-tumour cells 3T3. This observation suggests that the modification in the carbocylic group is significant for the antitumour action of RGD.

According to our recent investigations, as well as our further work, which is in progress, these new members of RGD are easily transformed into derivatives with improved pharmacological properties, or they can be used as building blocks for combinatorial peptide libraries.

\section{Materials and Methods}

\section{Synthesis}

The peptides $\mathbf{1}$ and $\mathbf{2}$ were synthesized manually by the solid phase method using Fmoc chemistry on (2-Chloro) chlorotrityl resin (Iris Biotech $\mathrm{GmbH}$, Germany) using Fmoc/tBu methodology. Fmoc groups were removed using 20\% piperidine in DMF. Coupling reactions were performed using Fmoc-amino acid/HBTU/HOBt/DIEA/ resin in molar ratio of $3 / 3 / 3 / 9 / 1$. The coupling and deprotection reactions were checked by the Kaiser test. Peptide removal from the resin and the removal of side chain protection groups were performed using 95\% TFA with $0.3 \%$ TES treatment. The synthesis of RGD-OMe was prepared by classical solution procedure using mixed anhydride coupling reactions. The final products were purified by gel filtration on a Sephadex G-10 column. The peptide purity was monitored on a RP-HPLC column Atlantis ${ }^{\mathrm{TM}} \mathrm{dC}_{18}, 4.6 \times 150 \mathrm{~mm}$, particle size $5 \mu \mathrm{m}$, mobile phase: acetonitrile/deionised water $40 / 60(\mathrm{v} / \mathrm{v})$, at $25^{\circ} \mathrm{C}$, flow rate: $1 \mathrm{ml} / \mathrm{min}$, and UV detection - $206 \mathrm{~nm}$. The correct molecular masses were confirmed by ESI-MS. For $\mathrm{R}\left(\mathrm{NO}_{2}\right) \mathrm{GD}, \mathbf{G F}-\mathrm{C}_{12} \mathrm{H}_{21} \mathrm{O}_{7} \mathrm{~N}_{7},[\mathrm{MH}]^{+}$calculated -375.34, [MH] $]^{+}$observed -375.36; CavGD, GF $\mathrm{C}_{11} \mathrm{H}_{21} \mathrm{O}_{6} \mathrm{~N}_{6},[\mathrm{MH}]^{+}$calculated $-333.32,[\mathrm{MH}]^{+}$observed -333.19; RGD-OMe, GF - $\mathrm{C}_{13} \mathrm{H}_{24} \mathrm{O}_{5} \mathrm{~N}_{6},[\mathrm{MH}]^{+}$calculated $-344.37,[\mathrm{MH}]^{+}$observed -344.59 .

\section{Cell cultures}

The 3T3 (standard mouse embryonic fibroblast cell line), MCF-7 (human breast cancer cell line) and HepG2 
(human liver hepatocellular carcinoma cell line) cells were cultured in Dulbecco Modified Eagle's medium (DMEM) (Gibco, Austria) supplemented with 10\% fetal bovine serum (Gibco, Austria), $100 \mathrm{U} / \mathrm{ml}$ penicillin (Lonza, Belgium) and $0.1 \mathrm{mg} / \mathrm{ml}$ streptomycin (Lonza, Belgium) under a humidified $5 \% \mathrm{CO}_{2}$ atmosphere at $37^{\circ} \mathrm{C}$. Plastic flasks supplied by Greiner, Germany, were used to grow the cells. Cells were trypsinized using Trypsin-EDTA (FlowLab, Australia) when they reached approximately $80 \%$ confluence. For experiments the cells in exponential phase of growth after treatment with Trypsin-EDTA were seeded into 96-well plates (Greiner, Germany) in a concentration $2 \times 10^{4}$ cells/well. 24 hours incubation post seeding (under a humidified $5 \% \mathrm{CO}_{2}$ atmosphere at $37^{\circ} \mathrm{C}$ ) allowed the cells to attach to the wells.

\section{Cytotoxicity assay}

The cultivated cells were treated with RGD and its analogues (2-4) in a wide concentration range (2 - 0.015 $\mathrm{mM}$ ). Untreated cells were used as controls. Empty wells were blank controls. Cytotoxicity was measured by colorimetric assay based on tetrasolium salt MTT (3-(4,5-Dimethylthiazol-2-yl)-2,5-diphenyl tetrazolium bromide) (Sigma Chemical Co.). The MTT assay is based on the protocol first described by Mossman (1983). In this

\section{References}

1. Ung P, Winkler DA. Tripeptide Motifs in Biology: Targets for Peptidomimetic Design J Med Chem 2011; 54:1111-1125

2. Ruoslahti E, Pierschbacher MD. New perspectives in cell adhesion: RGD and integrins. Science 1987; 238: 491-497.

3. Sasaki M, Kleinman HK, Huber H, Deutzmann R, YamadaY. Laminin, a multidomain protein. The A chain has a unique globular domain and homology with the basement membrane proteoglycan and the laminin B chains. J Biol Chem 1988; 263: 16536-16544.

4. Humphries M J, Olden K, Yamada KM. A synthetic peptide from fibronectin inhibits experimental metastasis of murine melanoma cells. Science 1986; 233: 467-470.

5. Saiki I, Murata J, Iida J, Sakurai T, Nishi N, Matsuno K, Azuma I. Antimetastatic effects of synthetic polypeptides containing repeated structures of the cell adhesive Arg-Gly-Asp (RGD) and Tyr-Ile-Gly-Ser-Arg (YIGSR) sequences. Br J Cancer 1989; 60: 722-728.

6. Saiki I, Murata J, Makabe T, Nishi N, Tokura S, Azuma, I. Inhibition of tumor angiogenesis by a synthetic cell-adhesive polypeptide containing the Arg-Gly-Asp (RGD) sequence of fibronectin, poly(RGD). Jpn J Cancer Res 1990; 81: 668-675.

7. Saito N, Mitsuhashi M, Hayashi T, Narumo C, Nagata H, Soyama K, Kameoka S, Harumiya S, Fujimoto D. Inhibition of hepatic metastasis in mice treated with cell-binding domain of human fibronectin and angiogenesis inhibitor TNP-470. Int J Clin Oncol 2001; 6: 215-220.

8. Murata J, Saiki I, Ogawa R, Nishi N, Tokura S, Azuma I. Molecular properties of poly(RGD) and its binding capacities to metastatic melanoma cells. Int J Pept Protein Res 1991; 38: $212-$ 217.

9. Sogabe T, Nishimura S, Chung YS, Sowa M. Role of tripeptide assay, living cells reduce the yellow MTT to insoluble purple formazan crystals. The peptides were dissolved in dimethyl sulfoxide (DMSO). The final concentration of DMSO in samples did not affect the viability of the cells. The assay was performed 24 hours after treatment with the amino acid analogues. For this purpose, MTT solution was prepared at $5 \mathrm{mg} / \mathrm{ml}$ in PBS and was filtered through a $0.2 \mu \mathrm{m}$ filter. Then $1 \mathrm{ml}$ of MTT solution was added to $15 \mathrm{ml}$ DMEM and $100 \mu \mathrm{l}$ of this solution were added into each well, including the cell free blank wells. Then the plates were further incubated for 3 hours to allow MTT to be metabolized and the supernatant was removed. 100 $\mu 1 /$ well DMSO/etanol (1/1) was added. The plates were placed in a microtitre-plate shaker for $10 \mathrm{~min}$ at room temperature to thoroughly mix the purple formazan into the solvent. ELIZA plate reader (TECAN, Sunrise TM, Grodig/Sazburg, Austria) was used for reading the results. Optical density (OD) was determined at a wavelength of $540 \mathrm{~nm}$ and a reference wavelength of $620 \mathrm{~nm}$. Cell cytotoxicity determined by MTT assay was expressed as per cent of dead cells:

$\%$ cytotoxicity $=(1-($ OD sample - OD blank control $) /$ (OD control - OD blank control)) x 100

PrizmaPlot.4 (ANOVA-test) was used for statistical analysis.

Arg-Gly-Asp (RGD) on adhesiveness of human pancreatic cancer cell, PANC-1 to extracellular matrix. Nippon Rinsho 1995; 53: 1648-1652.

10. 10. Meyer A, Auernheimer J, Modlinger A, Kessler H. Targeting RGD recognizing integrins: drug development, biomaterial research, tumor imaging and targeting. Curr Pharm Des 2006; 12:2723-2747.

11. 11. Yamamoto, Y., Tsutsumi, Y. and Mayumi, T. Molecular design of bioconjugated cell adhesion peptide with a water-soluble polymeric modifier for enhancement of antimetastatic effect. Curr Drug Targets 2002; 3: 123-130.

12. 12. Tsuchiya Y, Sawada S, Tsukada K, Saiki I. A new pseudopeptide of Arg-Gly-Asp (RGD) inhibits intrahepatic metastasis of orthotopically implanted murine hepatocellular carcinoma. Int $J$ Oncol 2002; 20: 319-324.

13. Saiki I, Yoneda J, Igarashi, Y, Aoki M, Kusunose N, Ono K. Azuma I. Antimetastatic activity of polymeric RGDT peptides conjugated with poly(ethylene glycol). Jpn J Cancer Res 1993; 84: 558-565.

14. Fujii H, Nishikawa N, Komazawa H, Orikasa A, Ono M, Itoh I, Murata J, Azuma I, Saiki I. Inhibition of tumor invasion and metastasis by peptidic mimetics of Arg-Gly Asp (RGD) derived from the cell recognition site of fibronectin. Oncol Res 1996; 8: 333-342.

15. Mukhopadhyay S, Barnés CM, Haskel A, Short SM, Barnes KR, Lippard SJ. Conjugated Platinum(IV)-Peptide Complexes for Targeting Angiogenic Tumor Vasculature. Bioconjugate Chem. 2008; 19: 39-49.

16. Raha S, Paunesku T, Woloschak G. Peptide-mediated cancer targeting of nanoconjugates. WIREs Nanomedicine and Nanobiotechnology 2011; 3: 269-281. 
17. Wang W, Borchardt R T, Wang B. Orally active peptidomimetic RGD analogs that are glycoprotein IIb/IIIa antagonists. Curr Med Chem. 2000; 7:437-453.

18. Pajpanova T, Georgiev K, Dzimbova T, Georgieva M, Staneva D, Miloshev G. In vitro Assessment of the Cytotoxic Effects of Novel RGD-Mimetics, in Peptides: Building Bridges Proceedings of the $22^{\text {nd }}$ American Peptide Symposium (Lebl M. ed.), 2011, Prompt Scientific Publishing, San Diego, USA, pp. 190-191.

19. Bence AK, Worthen DR, Adams VR, Crooks PA. The antiproliferative and immunotoxic effects of L-canavanine and L-canaline. Anticancer Drugs 2002; 13: 313-320.

20. Miersh J, Grancharov K, Pajpanova T, Neumann D, Tabakova S, Stoev S, Krauss G-J, Golovinsky E. Synthesis and biological activity of canavanine hydrazide derivatives. Amino Acids 2000; 18: 41-59.

21. Dzimbova T, Iliev I, Georgiev K, Detcheva R, Balacheva A, Pajpanova T. In vitro assessment of the cytotoxic effects of sulfoarginine analogues and their hydrazide derivatives in $3 \mathrm{~T} 3$ and HepG2 cells. Biotechnol \& Biotechnol Eq 2012; 26: 180-184. 